\title{
Leading In Context: A Review Of Leadership Styles To Inform School Effectiveness In Small Island States
}

By

\author{
${ }^{1}$ Dr. Chryselda Caesar
}

\begin{abstract}
This paper examines different models and theories of leadership with a view to discern relevance, meaning and applicability to a small state, St Lucia. It reviews the evolution and distinguishing features of leadership and compares selected models in order to determine significance to St. Lucia context for achieving effective schools. Different school leadership models evolved to suit societal changes, educational reforms and demands and perceptions of educational researchers who viewed schools as organizations based on corporate organization models, but exhibited greater complex and dynamism. Other researchers viewed schools as communities with a network of interconnecting people and relationships, with varying degrees of commitments and conflicting expectations, thus creating a unique environment in each school.

Apprehension about the degree of applicability of these models with regard to outcomes and the quality of schooling that students require in this challenging era, led to the development of new leadership theories. These new leadership models suggest that school leaders should to be driven by a noble and morale purpose. However the literature seems to indicate that transformational models and new leadership concepts are theoretical and have not been empirically tested in schools. Then again, if available, the few empirically based theories are context specific; they are researched in developed and different countries with completely different circumstances and may not be easily transferable. Adoption and application of these models are dependent on the prevailing circumstances and environment.
\end{abstract}

Key Words: Leadership, team building, education, behavior, moral.

\section{Introduction}

Small island states place a great deal of emphasis on education with the expectation that education can provide the economic, social, political and cultural leverage out of poverty. For this reason St. Lucia, a small island, a member of the Organization of Eastern Caribbean States (OECS) spares no effort, despite the economic constraints, to provide universal primary and secondary education to

${ }^{1}$ Organizational Improvement and Performance Management Consultant

E- lecturer University of the West Indies 
the student population. No doubt the availability of resources will greatly compromise the delivery of quality education in small developing states. It is not uncommon to find students with no text or copy books, teachers teaching with limited training, dearth of learning resources and frequent disruption of electricity and water in the schools.

At the same time small island states with small population and fragile economies are subject to global and economic competitiveness, technological changes and advancement, migration and brain drain, imbalance in import and export expenditure, poverty and illiteracy, inadequate health, all occurring within a continuous changing environment.

The sum total and interactions of all the elements at the micro and macro level, frequent change of government and government policies and priorities, the public's expectations of schools, internal and external influences have created a unique challenge for the schools in small island states, St Lucia no exception.

While providing education is an expensive exercise, the commitment to provide greater access is reflected in the percentage of revenue allocated for this exercise. For example over the last ten years from 1994 to 2004, approximately 20\% to $28 \%$ of the country's recurrent annual budget was allocated to the Ministry Of Education for improvement and maintenance of the education system. The government contributes approximately $10 \%$ of the annual budget to education (Government of St. Lucia Estimates, 1993/1994- 2003/2004). According to the Caribbean Education Strategy Report (2001) of the 21 small states in the Caribbean region, St. Lucia occupies the $5^{\text {th }}$ place, in terms of percentage of GDP and education expenditure. It spends $7.2 \%$ of gross domestic product on education.

Despite government's commitment to expand access to education, students' performance in standardized tests reveals low achievement at the 3 different grades levels over the past five years. Approximately 36\% of primary students (approximately 3194) who wrote the Grade 2 Standardize Test passed with a score at or above $60 \%$. Approximately 3000 students wrote the grade 4 Minimum Standards test, but less than $30 \%$ attained the expected standard pass score of $60 \%$. At the grade 6 level, the national mean has been relatively low (below 50\%). What is more alarming is that more than $50 \%$ of primary school cohorts perform below the national mean at the national common entrance examination (the qualifier examination to gain access to secondary school) and are unable to satisfy the entry requirements for secondary education. The national mean has been lowered in several instances in order to accept borderline students (Government of St. Lucia, Education Statistical Digest,2003). 
It appears that the significant investment made in education does not seem to reflect in students' achievement. The concern for the delivery of quality education has been articulated at governmental and regional level in numerous forums and policy frameworks such as:

- The Organization of Eastern Caribbean States Education development Project (OECS 2001)

- The Future of education in the Caribbean: CARICOM Regional Education Policy (1996)

- $\quad$ Education for All 2000-2015 (OECS 2000)

- $\quad$ St. Lucia sector development Plan 2000-2005 (Ministry of education 2000)

\section{Quality Education and School Leadership}

This concern for quality education is not unique to St. Lucia. According to $\mathrm{Gu}$ (2001, p. 135) 'that concern for quality education seem to be a worldwide issue'. In 1983 the United States Government expressed anxiety over the quality of education delivered in a published article entitled 'A Nation at Risk'.

A variety of factors influence the delivery of quality education, among which leaders appear to play a pivotal role. The association between delivery of quality education and leaders is not new. Harris (2003) claims that the challenges in education are numerous but the potential of leaders to influence schools still remains indisputable, and that the importance of school leaders and school improvement has been demonstrated in both theory and practice. Other Educational researches (Fullan 2003, 2001, Hargreaves 1994, Harris 2003) have attempted to establish the relatedness between leadership and school improvement. Bell et al. (2003) also endorse that that practitioners and policy makers are now acknowledging that school leadership and management play a significant role in developing successful schools.

Ribbins (2001) confirm that the relationship between leadership and school effectiveness is widely accepted by many countries, more so by government ministers who very often rate quality of leadership as a significant factor of effective schools, without understanding or acknowledging that school leaders operate within a context. The relevance of context is critical to school outcomes, but the leader's behaviour has an indirect influence on students' performance (Hallinger and Heck, 1998). Notwithstanding the relevance of context, Aspin et al. (1994) equivocally assert that those who are charged with school leadership and management have a major responsibility for promoting quality education by ensuring that teaching and learning the primary task of schooling, takes place in 
the classroom. Considering that the influence of leadership on schools and students' performance remains irrefutable, this paper seeks to undertake:

1. A review of leadership models and styles to understand how these concepts are applicable,and,how they may influence school effectiveness in a smalldeveloping state.

2. The application of selected models and approaches to school leadership.

3. A critique of the application and appropriateness of leadership models

\section{Overview of leadership Models and Styles}

Harris (2003, p.1) posits 'there is a groundswell towards leadership as empowerment, transformation and community building and away from the great man theory... but there is a powerful argument for looking at alternative ways of leading and looking for competing theories of leadership and challenging the orthodoxy of equating leadership with the efforts of one man'. Sergiovanni (2001, p.55) too seems to share the same sentiment in this expression 'it means that the superhero images of leadership will not work'

The leadership model that is more likely to improve schools will be grounded in collaborative work and team building (Chapman 2003). Sergiovanni (1992) proposed six leadership models for schools based on declining order from highest (best) to lowest.

Table 1 Model proposed by Sergiovanni (1992)

\begin{tabular}{|l|l|l|}
\hline & Model & Underlying Features \\
\hline 1.(Highest order) & Moral & $\begin{array}{l}\text { Altruistic purpose, shared ideas, moral } \\
\text { community }\end{array}$ \\
\hline 2 & Professional & $\begin{array}{l}\text { Rational-technical, sense of responsibility, } \\
\text { acceptable professional norms and standards }\end{array}$ \\
\hline 3 & Technical & $\begin{array}{l}\text { Rational authority, technical expertise, norms, } \\
\text { rules, guidelines. regulations, }\end{array}$ \\
\hline 4 & Psychological & $\begin{array}{l}\text { Bargaining skills, reward-incentive, similar to } \\
\text { transactional model }\end{array}$ \\
\hline 5 (Lowest order) & Bureaucratic & $\begin{array}{l}\text { Mandate, job description rules, objectives, } \\
\text { regulation, time-on- task, chain of command }\end{array}$ \\
\hline
\end{tabular}

Sergiovanni (1994) argues that schools which operate as community families led by moral leaders are more likely to deliver quality education. 
Cheng (1994) on the other hand proposed an integrated model from perusing the work of Bolman and Deal (1991) who identified four leadership orientations as: structural, human resource, political and symbolic. He also incorporated Sergiovanni's (1984) models of leadership namely: technical, human, educational, symbolic and cultural in his integrated model. However, he emphasized three primary domains of leadership: the Behavioural, Affective and Cognitive as shown below in table 2 .

Table 2 Model proposed by Cheng (1994)

\begin{tabular}{|c|c|c|c|c|c|}
\hline \multirow[b]{2}{*}{$\begin{array}{l}\text { Affective } \\
\text { domain }\end{array}$} & Structural & Human & Political & Cultural & Educational \\
\hline & $\begin{array}{l}\text { Feelings } \\
\text { express } \\
\text { communicate }\end{array}$ & $\begin{array}{l}\text { Social } \\
\text { Commitment } \\
\text { Open } \\
\text { climate }\end{array}$ & $\begin{array}{l}\text { Conflict- } \\
\text { Resolution } \\
\text { accept- } \\
\text { diversity }\end{array}$ & $\begin{array}{l}\text { Participation } \\
\text { cultural of } \\
\text { excellence }\end{array}$ & $\begin{array}{l}\text { Professionalism } \\
\text { pursue } \\
\text { excellence }\end{array}$ \\
\hline $\begin{array}{l}\text { Behavioural } \\
\text { domain }\end{array}$ & $\begin{array}{l}\text { Provide } \\
\text { facilities and } \\
\text { resources } \\
\text { Procedure } \\
\text { and structure }\end{array}$ & $\begin{array}{l}\text { Social } \\
\text { interaction } \\
\text { friendship } \\
\text { collegiality }\end{array}$ & $\begin{array}{l}\text { Build } \\
\text { alliance } \\
\text { tactics and } \\
\text { power to } \\
\text { implement } \\
\text { change }\end{array}$ & $\begin{array}{l}\text { Behaviour- } \\
\text { support } \\
\text { school } \\
\text { culture } \\
\text { reflect on } \\
\text { norms }\end{array}$ & $\begin{array}{l}\text { Effective } \\
\text { practices } \\
\text { facilitate } \\
\text { technological } \\
\text { change }\end{array}$ \\
\hline $\begin{array}{l}\text { Cognitive } \\
\text { domain }\end{array}$ & $\begin{array}{l}\text { Value policy } \\
\text { goal } \\
\text { achievement }\end{array}$ & $\begin{array}{l}\text { Human value } \\
\text { social } \\
\text { relations }\end{array}$ & $\begin{array}{l}\text { Inspire } \\
\text { highlight } \\
\text { Understand } \\
\text { meaning } \\
\text { Win/win } \\
\text { democratic } \\
\text { decision- } \\
\text { making }\end{array}$ & $\begin{array}{l}\text { Inspire to } \\
\text { perform } \\
\text { Celebrate } \\
\text { Visioning } \\
\text { Act out } \\
\text { vision }\end{array}$ & $\begin{array}{l}\text { Professional } \\
\text { development } \\
\text { Develop values } \\
\text { beliefs to fit in } \\
\text { era of } \\
\text { globalization } \\
\text { and technology }\end{array}$ \\
\hline
\end{tabular}

According to this model proposed by Cheng (1994), leaders should be directed by values, vision and goals (Cognitive), engage the human resource through commitment and participation (Affective) in effective practices (Behaviour) built on alliances and in a spirit of community. However the structural, human, political, cultural and educational leaders place more emphasize as the name implies on certain aspects of the school.

The influence of politics and culture in effective schools was recognized by both Bolman and Deal (1991) and Cheng (1994) through the emergence of the political and cultural leadership models proposed by them. These concepts are built on the recognition that conflicting perspectives are integral elements of organizational life (Ball 1993) where 'competing systems of interpretation' (Silverman (1970, p. 
38) exist. Deal (1988) and Firestone and Wilson (1989) also highlighted that effective schools have strong cultures.

Bush (1995) identified the following leadership models from the examination of the dynamics of organizations: formal; collegial; political; subjective; ambiguity and cultural. According to these models, the leadership role was dependent on the structure of the organizations, and that the organizations possibly dictated the behaviour of leaders. These models except the cultural model represent primarily traditional styles of leadership. He posits further that 'the six styles are all valid analysis but their relevance varies according to the context. Each organization may require a combination of approaches but no organization can be explained by using only one approach' (p. 142). These leadership models seem to highlight the unique influence of organizations on leadership behaviour. However later Bush and Glover (2002) identified yet a different set of typologies: managerial; instructional; transformational; transactional; participative; post-modern and contingent thus demonstrating alternative ways of explaining school leadership. These examples of leadership share similar characteristics to the models identified by Leithwood et al. (1999).

Leithwood et al. (1999, p. 8-29) proposed a set of six leadership models based on the review of American and UK Educational Journals as follows:

Table 3: Model proposed by Leithwoodet. al. (1999)

\begin{tabular}{|l|l|l|}
\hline & Models & Underlying Features \\
\hline 1 & Instrumental & Focus on student learning \\
\hline 2 & Morale & Duties, values, commitment, obligation \\
\hline 3 & Participating & Shared decision making \\
\hline 4 & Managerial & Target and goals, achievement oriented \\
\hline 5 & Contingent & Adapt to meet demands within context \\
\hline 6 & Transformational & Adopts a comprehensive approach to leading \\
\hline
\end{tabular}

The models proposed byLeithwood et al. (1999), Cheng (1994) and Sergiovanni (1992) reflect the four core concepts (human. structural, political and cultural modes of leadership) though they are expressed in different terminologies. They also reflect a departure from the hierarchy to a more egalitarian concept of leadership built upon shared purpose, action within context, participation and development of strong alliances through networking. Further examination of the models reveals that Bush (1995) leadership models are characterized by the nature of the organizations, whereas the other models are defined by the interaction of the people within the organization, implying that people give meaning to organizations and not the other way around. 
It is worthwhile examining the new leadership concept - transformational leadership or leaders of change who inspire and motivate their community of followers through idealized influence based on morale and ethical purpose (Fullan 2003 b).

\section{New Models of leadership}

New leadership concepts emphasize understanding meaning and promoting shared vision rather than set goals and task accomplishments (Bryman 1996, Fullan 2003 b). They are usually categorized as: transformational charismatic/visionary, transactional and transcendental. They share the common leadership characteristic of heroism, inspirational and charismatic styles of leading (Robinson, 2001).

\subsection{Transformational and Transactional leadership Approaches:}

Transactional leaders achieve their motives and purpose by fulfilling or satisfying the motives of followers through rewards and incentives (Robinson, 2001). The strength of transactional leadership is dependent on the bargaining skills of the leader (Peeke, 2003). Unlike transactional leaders, transformational leaders engage in transformational change by inspiring their followers. They consider the technical aspect, but the emphasis is on the moral purpose, participation of others, sharing of ideas and resources. Transformational leaders foster learning communities through interactions and problem solving by encouraging enquiry and exploration (Fullan, 2003 b).

With reference to leaders transforming systems, Fullan (2003b, pp. 33-34) admits 'I cannot claim that we know exactly how to accomplish sustainability and system transformation, because no one has ever done it before', but continues to support it by adding 'there is enough theoretical arguments and instance of strategic evidence to build on'. Lakomski (2001, p. 118) from a more critical perspective indicates 'one of the advocatedstrengths of the transformational leader is the ability to transform people and incite them to perform beyond expectations'.

\subsection{Transcendental leadership:}

Morrison (2002) describes transcendental leadership as one who is deeply committed to service and acts as a servant to serve others so that they can transcend themselves. Sergiovanni (1992) refers to this form of service as servant leadership. Such leaders look at the needs, motives and agendas of collaborators and seek to address them in a non-manipulative way. They engage the community 
by sharing power and decision-making processes. These leaders possess a great sense of vocation which may have stemmed from religious beliefs.

\section{The application of models and approaches to school leadership}

Ribbins (2001, p.21-32) cautioned against the use of traditional paradigms of leadership in education, explaining that leadership should be studied within situational context. He stated 'I began the notion that the world of the school, and that of the principal within it, is a highly complex one in which to an extent, there are as many realities as there are individuals', and there should be a link between the interactions of agency and structure and the contextual portraits of leadership. Robinson (2001) seems to support Ribbins (2001) by arguing that leadership should be linked to the task structures and recourses, as well as Bryan (1996) who proposed that leadership theories should not be decoupled from organizational context within which they reside.

The new leadership concepts are associated with intangible characteristics of visionary, motivator, transformational qualities, moral purpose and responsibility (Labomski, 2001). Fullan (2003 b), another advocate of the new concept proposed that redefining leadership involves going from splitting responsibilities unilaterally to doing so through dialogues, making appointments, assessable and subjecting performance and results to public scrutiny. Theories provide the platform for good practices or reinforcement of good practices; likewise leadership theories must be relevant for the reinforcement of good practice in education. But Holmes and Wayne (1989) argue that there is no empirical proven theory of school organization and likewise for school leaders. Ribbins (2001) also warns that if researchers of educational management or leadership turn to organizational theory for guidance in an attempt to understand and manage educational institutions, they will not find a single applicable theory but a multiplicity of approaches.

\section{Critique of the application of selected leadership models}

Traditional leadership theories were based on concepts of schools as organizations, whereby leaders were expected to maintain functional stability within schools. Then, the school leaders' emphasis were on improvement in teaching and learning methods, resources and school facilities, but that approach did not yield the expected outcomes (Cheng, 2002). The all-powerful decision makers were productive in that stable world then (Daft, 1999). However, now in this continuous changing society the search is for leaders who are partners, risktakers and facilitators. Schools are viewed now as communities built on 
relationships, shared values and goals with clear vision and the ability to communicate and build commitment to achieve these goals (Sergiovanni, 1994).

6.1 Comparison of leadership models:The traditional leaders identified by Bush (1995) as formal leaders, and the bureaucratic model which Sergiovanni (1992) identified as the lowest level are greatly simplified in that they considered mainly leadershipbehaviour. This form of leadership focused mainly on people and task and ignored the complexity of processes, interactions, and tensions within organizations, disregarding the external environment, the societal changes and cultural context surrounding their existence.

There is some degree of uncertainty about collegiality (Bush 1995) as a leadership model but rather as a behaviour as implied by Little (1990). However collegial interaction lays the groundwork for development and a means of generating positive change (Roseholtz, 1989). Examination of the models illustrated in by Sergiovanni (1992) table 1 on page 5; Cheng (1994) table 2 on page 6; and Leithwood et al. (1999) table 3 on page 8, reveal that they identified some similar characteristics (human relations, structural, political and cultural) to the contingency models of leadership by Hoy and Miskel, (2001) that flourished in the 80 's. On overview of contingency model is shown below as figure 1.

Figure 1 Contingency Models of leadership

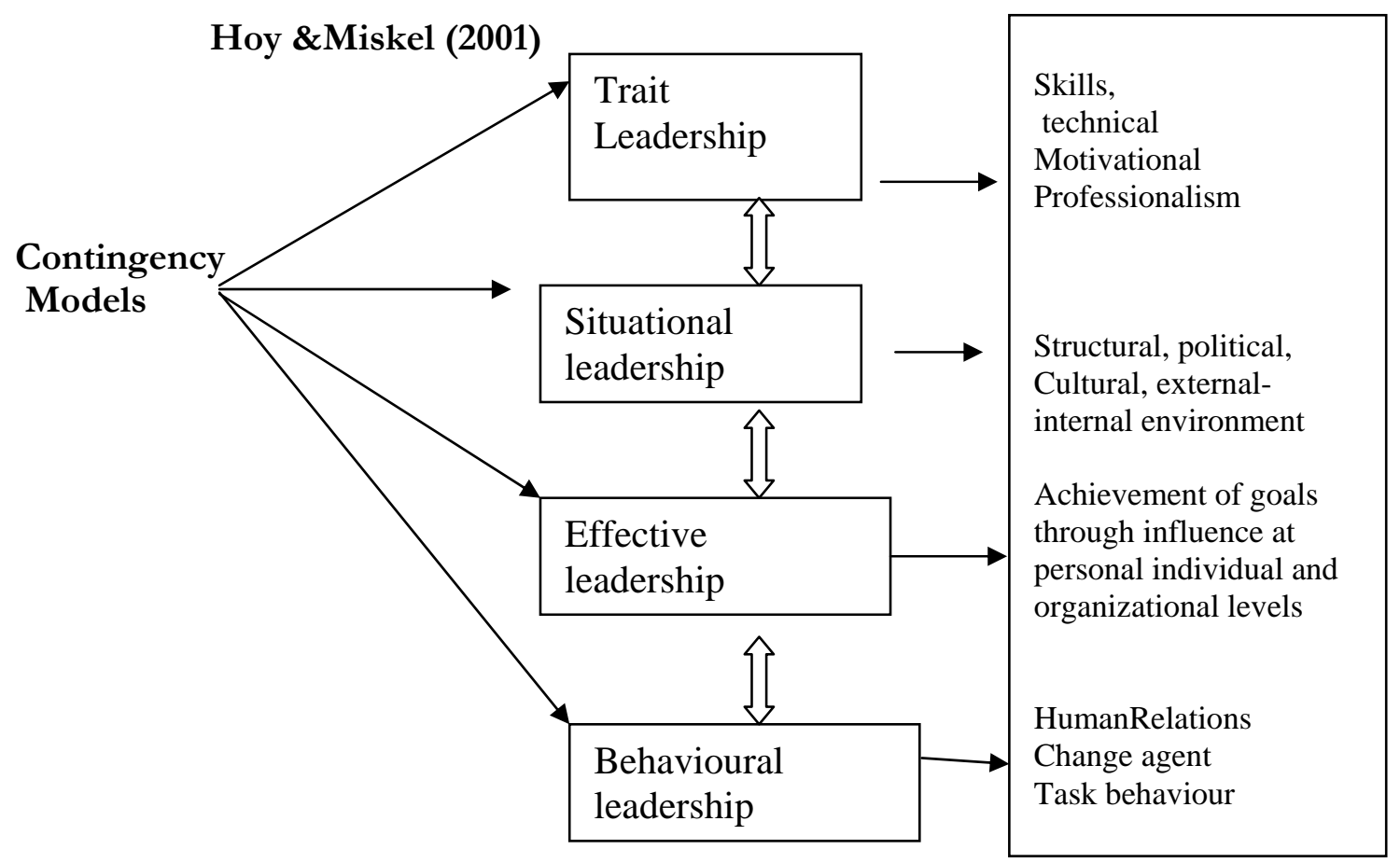


However there is an inherent problem because when these models by Sergiovanni (1992), Cheng (1994) and Leithwood et al. (1999) were applied independently they did not yield the expected results. Leaders who employed all the appropriate approaches were hindered by the surrounding internal and external situations. Different contexts and situations required different leader behaviour which in turn impacted on leadership styles (Bryman, 1996). These inherent problems led to the emergence of the contingency concepts by Hoy and Miskel (2001) which seek to emphasize that the characteristics of situations have a direct impact on leadership effectiveness.

The schema shown below, exhibited as figure 2, seeks to emphasize the direct relationship between leader effectiveness and situation/context.

Figure 2. A Modified contingency scheme
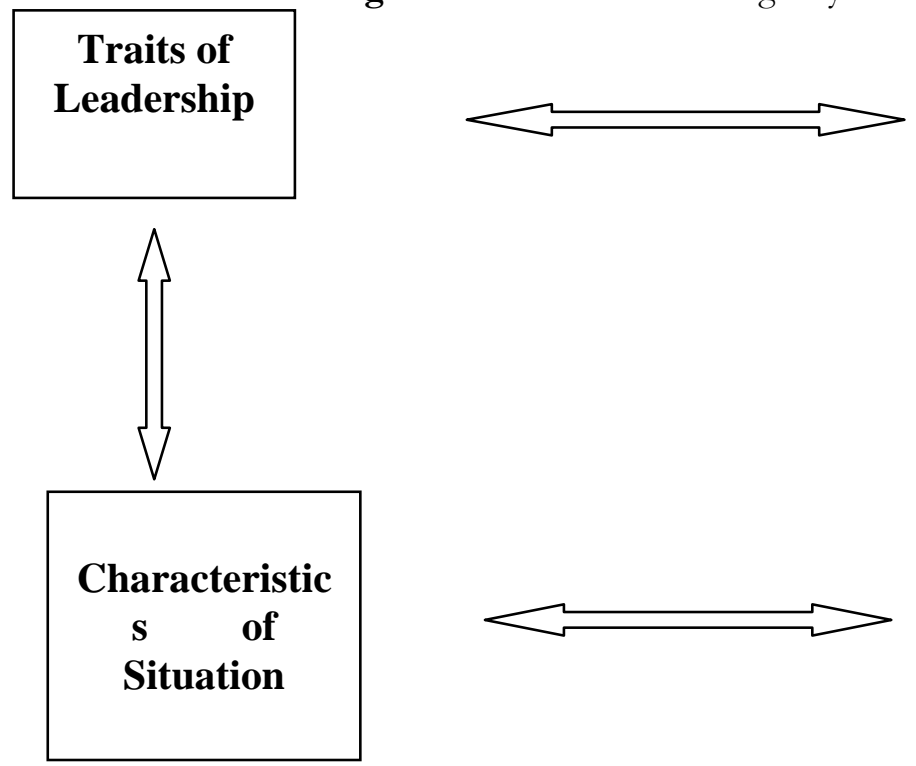

\section{Leadership \\ Behaviour}
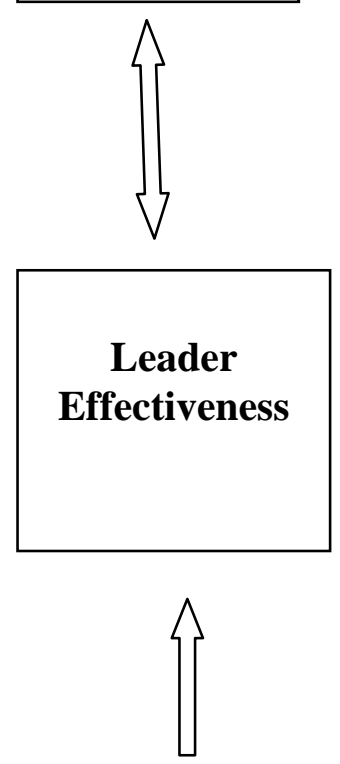

\section{Interaction between situation and effectiveness}

Although it was recognized that situational variables, both predictable and unpredictable impacted and influenced leader effectiveness, it proved difficult to 
answer the question "which style in what special situation" (Hoy \&Miskel 2001, p.406). This inherent problem created fresh interest in the new leadership theories as demonstrated by Fullan, (2003 a) and Morrison (2002).

New leadership theories surfaced in the 80's but flourished in the 90's. They evolved primarily to describe politicians and organizational leaders but later the concept was transferred to schools (Hallinger and Heck, 2002). They differ from the other models in that their leader concept is grounded in meaning, inspiration and vision with less emphasis on leader behaviour / tasks, situational influences, factors that are closely linked to school effectiveness.

They focused on one leader at the top who appealed to followers' emotions rather than intelligence. Charismatic leader akin to the great man theory is distinguished by strong moral convictions, dominance and influence over beliefs values and behaviour by sharing impressions visions of the future with followers (Fullan, 2003 b). Such leaders are positioned to create major cultural changes, a key component of capacity building within organizations.

\section{Conclusion}

Recognition of inadequacies of traditional models (Bryman, 1996) led to the emergence of the transformational model which was supposed to synthesize all the main concepts and address all noted weakness but, with one major difference. Transformational leadership beliefs are driven by a noble and morale purpose. Among their numerous characteristics, they are charismatic, visionaries, change agents, inspire commitment and trust, sustain and manage culture of excellence, risk-takers, share power, champion the needs of followers, goal oriented, manage conflicts, inspirational motivators, behaviour mirrors beliefs ( Leithwood et al. 1999, Fullan 2001, 2003 a).

Yukl (1994) argues new leaders create but cannot sustain change. Sustaining change, a feature of transactional leadership similar to the psychological model referred to by Sergiovanni (1994) engage their followers through reimbursements and rewards in exchange for service (elements of micro politics). Inherent weakness in the new leadership models are: leadership resides in one person, and situations and context can facilitate or weaken effects of charismatic or transformational leaders. They appeal to the cultural and symbolic aspects of organization but down play the technical, interpersonal and structural components of organizations (Yukl, 1994). Perhaps these new leadership models might be useful if massive one time changes are required otherwise they may not be functional in school situations.

While there is an urgent need to develop theories to address the multidirectional, complex, instability and unpredictability of school, these theories must be 
grounded and backed by practice (Cheng, 2002) to assist leaders in making the paradigm shift form the traditional to the new. Leithwood et al. (2002) cautioned that "many limitations of a theoretical and methodological nature remain in research on transformational leadership carried out to date". Besides there is a great deal of uncertainty over which theory is suitable due to lack of empirical evidence. Herein lies some of the weaknesses, and basis for cautious implementation ofleadership modelsin varied school contexts and landscapes.

\section{References}

Aspin, N. D., Chapman, D. J., Wilkinson, R. V. (1994) Quality Schooling: A pragmatic Approach to Some Current Problems Topics and Issues, London,Cassell.

Ball, S. J. (1993) The Micro politics of the School: Towards a theory of school organization, UK, Clays Ltd.

Bell,l., Bolam, R.,Cubillo, L. (2003) Foul is Fair and Fair is Foul: Conducting a Systematic Review of an Aspect of Leadership and Management in Anderson, L. and Bennett, N. (eds) Developing Educational Leadership: Using Evidence for Policyand Practice, London, Sage Publications Ltd.

Bolam, L. G., Deal, T. E. (1991) Images of Leadership Cambridge, HarvardUniversity Bryman, A., (1996) Leadership in Organization, London, Sage.

Bush, T. (1995) Theories of educational Management,London, Paul Chapman

Bush, T and Glover, d. (2002) School Leadership: Concepts and Evidence, Nottingham, NationalCollege for School Leadership.

Chapman, C. (2003) Building the Leadership Capacity for School Improvement: $A$ CaseStudy in Harris, A., Day, C., et al. (eds) Effective Leadership for SchoolImprovement, London, RoutledgeFalmer.

Cheng, C. Y. (2002) The Changing Context of School Leadership: Implications ofParadigm shift in Leithwood, K., Hallinger, P. (eds) Second International Handbook of educational Leadership and Administration, London, Kluwer Academic Publishers.

Cheng, Y. C. (1994) Principals Leadership as a Critical Indicator of school performance: Evidence from multi-levels of Primary schools, School Effectiveness and School Improvement, 5(3), 299-317.

Daft, L. R. (1999) Leadership Theory and Practice, USA, GeorgeProvel.

Deal, E. T. (1988) The Symbolism of Effective Schools in Westoby, A. (ed ) Culture andPower in Educational Organization, England, Open University Press.

OECS (2000) Education for All 2000-2015,OECS

Firestone, A. W., Wilson, L. B. (1989) Using Bureaucratic and Cultural Linkages to Improve Instruction: The Principals Contribution in Burdin L. J. (ed) School Leadership: A Contemporary Reader London, Sage Publications Inc.

Fullan, M. (2003,a) Change Forces with a Vengeance, London, RoutledgeFalmer

Fullan, M. (2001) The New Meaning of educational Change, 3rdedn. New York, Teachers College Press. 
Fullan, M. (2003 b,) The Morale Imperative of School Leadership, London, Sage Publications. Government of St Lucia Estimates, 1993/1994- 2003/2004)

Government of St. Lucia (2003) Education Statistical Digest, Ministry of Education.

Gu, M. (2001) Systems of Quality and Quality Assurance in Basic Education: Perspectives from Mainland China in Wong, K, C., Evers, W. S. (eds) Leadership for School Quality, London, RoutledgeFalmer

Hallinger, P., Heck, H. R. (1998) The Principal's role in School Effectiveness: A Review Of Empirical Research in Educational Administration Quarterly, 32, 1:5-144

Hallinger, P., Heck, H. R. (2002) What do you Call People with Vision? The role ofV ision Mission and Goals in School Leadership and Improvement in Leithwood, K., Hallinger, P. (eds) Second International Handbook of educational Leadership and Administration, London, Kluwer Academic Publishers.

Hargreaves, A. (1994) Changing Teachers Changing Times: Teachers Work and CultureIn the Post Modern Age, New York, Teachers College Press.

Harris, A. (2003) The changing Context of Leadership Research:Leading and Practice in Harris, A., Day, C,. et al.(eds) Effective Leadership for School Improvement, London, RoutledgeFalmer

Holmes, M., Waynne, E. (1989) Making The School an Effective Community: BeliefsPractice and Theory in School Administration, London, Falmer Press

Hoy, K, W., Miskel, G, C. ( 2001) Educational Administration- Theory Research andPractice, New York, McGraw-Hill.

Lakomski, G. (2001) Paradoxes and New Direction in Wong, K, C., Evers, W. S. (eds) Leadership for School Quality, London, RoutledgeFalmer

Leithwood, K,. Tomlinson, D., Genge, M. (2002) Transformational Leadership in Leithwood, K., Hallinger, P. (eds) Second International Handbook of educational Leadership and Administration, London, Kluwer Academic Publishers.

Leithwood, K., Janzi, T. and Steinbach, R. (1999) Changing Leadership for Changing Times, Burkingham, Open University Press.

Little, J. W. (1990) The Resistance of Privacy: Autonomy and Initative in Teachers'Professional Relations, Teachers College Record, 91: 500-36.

Morrison, K. (2002) School Leadership and Complexity Theory, London, RoutledgeFalmer.

Peeke, G. (2003) Leadership in Further Education in Brundrett, M., Burton, N., Smith, S. (eds) Leadership in Education, London, Sage Publications Ltd.

Ribbins, P. (2001) Regarding Principals: Leadership effects and Effectiveness andImprovement of Schools in Wong, K, C., Evers, W. S. (eds) Leadership forSchool Quality, London, RoutledgeFalmer

Rosenholtz, S. (1989) Teacher's Workplace: The Social organization of Schools,New York, Longman.

Sergiovanni,T. J.(2001) Leadership: What's In It For Schools, London, RoutledgeFalmer

Sergiovanni, T. J. (1994) Building Community in Schools, San Francisco, Jossey-Bass

Sergiovanni, T. J. (1984) Leadership and Excellence in Schools-How to get extraperformance in Schools, New York, Harcourt Brace.

Sergiovanni, T. J. (1992) Moral Leadership, San FranciscoJossey -Bass 
Silverman, D. (1970) The Theory of Organization,London, Heineman.

St. Lucia (2000) Education Sector Development Plan 2000-2005, St Lucia, Ministry of Education.

Yukl,G. (1994) Leadership in Organizations, NJ, Prentice Hall.

CARICOM (1996) The Future of Education in the Caribbean: CARICOM Regional Education Policy, Guyana, CARICOM.

The Organization of Eastern Caribbean States Education development Project OECS 2001

United Nations Report (1983) The Validity of Small Island States, New York UNCTAD 